Electronic Supplementary Information (ESI $\uparrow$ )

\title{
Self-Assembly of Biarsenate Capped Keggin Arsenomolybdates with Tetravanadium Substitution for Photocatalytic Degradation of Organic Dyes
}

\author{
Zhifeng Zhao*, † Bowen Cong, + Zhanhua Su*, $\dagger$ and Bairu Li† \\ $\dagger$ College of Mechanical and Electrical Engineering, Guangdong University of \\ Petrochemical Technology, Maoming 525000, China. \\ †School of Chemistry and Chemical Engineering, Harbin Institute of Technology, \\ Harbin 150022, China.
}




\section{Section I:}

1.Materials and methods.

2. Preparations of 1-4.

3. X-ray Crystallography.

\section{Section II:}

1. Figure S1 View of $\left\{\mathrm{As}_{3} \mathrm{Mo}_{8} \mathrm{~V}_{4}\right\}$ cluster.

2. Figure S2 The IR spectra of compounds 1-4.

3. Figure S3 The TG curves of compounds 1-4.

4. Figure S4 The XPS spectra of compound 1.

5. Figure S5 The XPS spectra of compound 2.

6. Figure S6 The XPS spectra of compound 3.

7. Figure S7 The XPS spectra of compound 4.

8. Figure S8 The solid state fluorescent spectra of 1-4 at room temperature.

9. Figure S9 Diffuse reflection spectrum of Kubelka-Munk (K-M) function versus energy $(\mathrm{eV})$ of $\mathbf{1 - 4}$.

10. Figure S10 Photo-degradation of the MB solution by $\mathbf{1 - 4}$ as the catalyst, recycled 5 times.

11. Figure S11 The XRD patterns of $\mathbf{1 - 4}$ before and after MB degradation for five 
cycles.

Section III:

1. Table S1 Crystallographic and structural refinement data for 1-4.

2. Table S2 Selected bond lengths $(\AA)$ and bond angles $\left({ }^{\circ}\right)$ of 1-4. 


\section{Experimental}

\section{Materials and methods}

All chemicals purchased were analytically grade. Elemental analyses were performed on a Elementar Vario EL III CHNOS elemental analyzer; As, Mo, V and $\mathrm{Cu}$ were analyzed on a SPECTROGREEN ICP-OES spectrometer. IR spectra were recorded in the range of $400-4000 \mathrm{~cm}^{-1}$ on a PerkinElmer Frontier IR spectrophotometer by using $\mathrm{KBr}$ pellets. TG curves were obtained on a NETZSCH STA 409 PC/PG under $\mathrm{N}_{2}$ at a heating rate of $10{ }^{\circ} \mathrm{C} \mathrm{min}^{-1}$. XPS spectra were acquired on a PHI-5702 spectromete. UV-vis-NIR spectra were measured on a PerkinElmer Lambda-35 spectrophotometer. XRD patterns were identified on Rigaku Dmax 2000 X-ray diffractomete with $\mathrm{Cu} \mathrm{K} \alpha$ radiation. The fluorescence spectra were carried out on F-7000 FL spectrophotometer.

Synthesis of (bix) $\left[\mathrm{H}_{3} \mathrm{As}_{2}{ }^{\mathrm{III}} \mathrm{As}^{\mathrm{V}} \mathrm{Mo}_{8} \mathrm{~V}_{4}{ }^{\mathrm{IV}} \mathrm{O}_{40}\right][\mathrm{Cu}(\text { bix })]_{2} \cdot 3 \mathrm{H}_{2} \mathrm{O}(\mathbf{1})$

A mixture of $\mathrm{CuCl}_{2} \cdot \mathrm{H}_{2} \mathrm{O}(0.3417 \mathrm{~g}, 2.0 \mathrm{mmol}), \mathrm{NH}_{3} \mathrm{VO}_{3}(0.1136 \mathrm{~g}, 0.97 \mathrm{mmol})$, $\mathrm{NaAsO}_{2}(0.1513 \mathrm{~g}, 1.16 \mathrm{mmol}), \mathrm{MoO}_{3} \cdot \mathrm{H}_{2} \mathrm{O}(0.8237 \mathrm{~g}, 5.09 \mathrm{mmol}), \operatorname{bix}(0.1214 \mathrm{~g}$, $0.51 \mathrm{mmol})$ and $\mathrm{H}_{2} \mathrm{O}(18 \mathrm{ml})$ was stirred for $1 \mathrm{~h}$ and sealed in a Teflon-lined reactor $(25 \mathrm{ml})$, which was kept for $72 \mathrm{~h}$ at $180^{\circ} \mathrm{C}$ and cooled to $25^{\circ} \mathrm{C}$, colourless block crystals were collected (Yield: 35\%, based on Mo). Anal. calcd for $\mathrm{C}_{42} \mathrm{H}_{50} \mathrm{As}_{3} \mathrm{Cu}_{2} \mathrm{Mo}_{8} \mathrm{~N}_{12} \mathrm{O}_{43} \mathrm{~V}_{4}(\mathrm{Mr}=2734.08): \mathrm{C}, 18.45 ; \mathrm{H}, 1.84 ; \mathrm{N}, 6.15 ; \mathrm{As}, 8.22 ;$ $\mathrm{Cu}, 4.65 ; \mathrm{V}, 7.45 ; \mathrm{Mo}, 28.07 \%$. Found: C, 18.62; H, 1.91; N, 6.03; As, 8.28; Cu, 
4.72; V, 7.49; Mo, 28.11\%. IR data $\left(\mathrm{KBr}, \mathrm{cm}^{-1}\right): 3448(\mathrm{~s}), 2924(\mathrm{~m}), 2842(\mathrm{w})$, 2327(w), 1633(s), $1417(\mathrm{w}), 1047(\mathrm{w}), 949(\mathrm{~m})$, 867(s), 790(m), 569(s).

Synthesis of $\left[\left\{\mathrm{HAs}_{2}{ }^{\mathrm{III}} \mathrm{As}^{\mathrm{V}} \mathrm{Mo}_{8} \mathrm{~V}_{4}{ }^{\mathrm{IV}} \mathrm{O}_{40}\right\}\{\mathrm{Cu}(\mathrm{bib})\}_{2}\right][\mathrm{Cu}(\mathrm{bib})]_{2}(2)$

A mixture of $\mathrm{CuCl}_{2} \cdot \mathrm{H}_{2} \mathrm{O}(0.3327 \mathrm{~g}, 1.95 \mathrm{mmol}), \mathrm{NH}_{3} \mathrm{VO}_{3}(0.1244 \mathrm{~g}, 1.06 \mathrm{mmol})$, $\mathrm{NaAsO}_{2}(0.1545 \mathrm{~g}, 1.19 \mathrm{mmol}), \mathrm{MoO}_{3} \cdot \mathrm{H}_{2} \mathrm{O}(0.8645 \mathrm{~g}, 5.348 \mathrm{mmol}), \mathrm{bib}(0.1233 \mathrm{~g}$, $0.52 \mathrm{mmol})$ and $\mathrm{H}_{2} \mathrm{O}(18 \mathrm{ml})$ was stirred for $1 \mathrm{~h}$ and sealed in a Teflon-lined reactor $(25 \mathrm{ml})$, which was kept for $72 \mathrm{~h}$ at $180^{\circ} \mathrm{C}$ and cooled to $25^{\circ} \mathrm{C}$, blue block crystals were collected (Yield: 41\%, based on Mo). Anal. calcd for $\mathrm{C}_{56} \mathrm{H}_{54} \mathrm{As}_{3} \mathrm{Cu}_{4} \mathrm{Mo}_{8} \mathrm{~N}_{16} \mathrm{O}_{40} \mathrm{~V}_{4}(\mathrm{Mr}=3041.35): \mathrm{C}, 23.11 ; \mathrm{H}, 1.79 ; \mathrm{N}, 7.37 ; \mathrm{As}$, 7.39; Cu, 8.36; V, 6.69; Mo, 25.24\%. Found: C,23.16; H, 1.76; N, 7.33; As, 7.45; $\mathrm{Cu}, 8.42 ; \mathrm{V}, 6.63 ; \mathrm{Mo}, 25.29 \%$. IR data $\left(\mathrm{KBr}, \mathrm{cm}^{-1}\right): 3443(\mathrm{~s})$, 2924(m),2852(w), 2363(w), 1628(s), $1484(\mathrm{w}), 1397(\mathrm{~m}), 1058(\mathrm{w}), 949(\mathrm{~m})$, 877(s), 765(s), 605(w),528(w).

Synthesis of $\quad\left[\left\{\mathrm{As}_{2}{ }^{\mathrm{III}} \mathrm{As}^{\mathrm{V}} \mathrm{Mo}_{8} \mathrm{~V}_{4}{ }^{\mathrm{IV}} \mathrm{O}_{40}\right\}\left\{\mathrm{Cu}_{3}(\mathrm{tib})_{2}\left(\mathrm{H}_{2} \mathrm{O}\right)_{2}\right\}\right][\mathrm{Cu}(\mathrm{tib})$ $\left.\left(\mathrm{H}_{2} \mathrm{O}\right)\right]_{2} \cdot 4 \mathrm{H}_{2} \mathrm{O}(3)$

A mixture of $\mathrm{CuCl}_{2} \cdot \mathrm{H}_{2} \mathrm{O}(0.34 \mathrm{~g}, 1.99 \mathrm{mmol}), \mathrm{NH}_{3} \mathrm{VO}_{3}(0.1238 \mathrm{~g}, 1.06 \mathrm{mmol})$, $\mathrm{NaAsO}_{2}(0.1433 \mathrm{~g}, 1.10 \mathrm{mmol}), \mathrm{MoO}_{3} \cdot \mathrm{H}_{2} \mathrm{O}(0.6456 \mathrm{~g}, 3.99 \mathrm{mmol})$, tib(0.2156g, $0.78 \mathrm{mmol})$ and $\mathrm{H}_{2} \mathrm{O}(18 \mathrm{ml})$ was stirred for $1 \mathrm{~h}$ and sealed in a Teflon-lined reactor $(25 \mathrm{ml})$, which was kept for $72 \mathrm{~h}$ at $180^{\circ} \mathrm{C}$ and cooled to $25^{\circ} \mathrm{C}$, blue block crystals were collected (Yield: 43\%, based on Mo). Anal. calcd for $\mathrm{C}_{60} \mathrm{H}_{64} \mathrm{As}_{3} \mathrm{Cu}_{5} \mathrm{Mo}_{8} \mathrm{~N}_{24} \mathrm{O}_{48} \mathrm{~V}_{4}(\mathrm{Mr}=3403.14): \mathrm{C}, 21.17 ; \mathrm{H}, 1.89 ; \mathrm{N}, 9.89 ;$ As, 
2.44; $\mathrm{Cu}, 9.34 ; \mathrm{V}, 5.99 ; \mathrm{Mo}, 22.55 \%$. Found: C, 21.22; H, 1.93; N, 9.92; As,

2.39; $\mathrm{Cu}, 9.38 ; \mathrm{V}, 5.91 ; \mathrm{Mo}, 22.50 \%$. IR data $\left(\mathrm{KBr}, \mathrm{cm}^{-1}\right): 3438(\mathrm{~s})$, 2975(w),2363(m),1627(s), 1417 (m), 1047 (w), 980(s), 862(s), 785(s), $610(\mathrm{~m}), 522(\mathrm{~s})$

Synthesis of $\left[\mathrm{HAs}_{2}{ }^{\mathrm{III}} \mathrm{As}^{\mathrm{V}} \mathrm{Mo}_{8} \mathrm{~V}_{4}{ }^{\mathrm{IV}} \mathrm{O}_{40}\right]\left[\mathrm{Cu}_{2}(\mathrm{bih})\right]_{2}(\mathbf{4})$

A mixture of $\mathrm{CuCl}_{2} \cdot \mathrm{H}_{2} \mathrm{O}(0.3629 \mathrm{~g}, 2.13 \mathrm{mmol}), \mathrm{NH}_{3} \mathrm{VO}_{3}(0.1037 \mathrm{~g}, 0.89 \mathrm{mmol})$, $\mathrm{NaAsO}_{2}(0.1628 \mathrm{~g}, 1.25 \mathrm{mmol}), \mathrm{MoO}_{3} \cdot \mathrm{H}_{2} \mathrm{O}(0.8500 \mathrm{~g}, 5.25 \mathrm{mmol})$, bih(0.1206 g, $0.55 \mathrm{mmol})$ and $\mathrm{H}_{2} \mathrm{O}(18 \mathrm{ml})$ was stirred for $1 \mathrm{~h}$ and sealed in a Teflon-lined reactor $(25 \mathrm{ml})$, which was kept for $72 \mathrm{~h}$ at $180^{\circ} \mathrm{C}$ and cooled to $25^{\circ} \mathrm{C}$, blue block crystals were collected (Yield: 37\%, based on Mo). Anal. calcd for $\mathrm{C}_{32} \mathrm{H}_{50} \mathrm{Ass}_{6} \mathrm{Cu}_{6} \mathrm{Mo}_{16} \mathrm{~N}_{16} \mathrm{O}_{89} \mathrm{~V}_{8}(\mathrm{Mr}=4856.26): \mathrm{C}, 7.91 ; \mathrm{H}, 1.04 ; \mathrm{N}, 4.62 ;$ As,9.26; $\mathrm{Cu}, 7.85 ; \mathrm{V}, 5.99 ; \mathrm{Mo}, 31.61 \%$. Found: C, 7.96; H, 1.10; N, 4.70; As, 9.29; Cu, 7.79; V,6.05; Mo, 31.67\%. IR data $\left(\mathrm{KBr}, \mathrm{cm}^{-1}\right):$ 3443(s), 2358(w), 1603(m), $1438(\mathrm{~m}), 1309(\mathrm{w}), 1243(\mathrm{w}), 1159(\mathrm{w})$, 1022(w), 949(s), 872(s), 774(s), 667(m), 600(m), 538(s).

\section{Photodegradation properties process}

Compounds 1-4 (50 mg) and $100 \mathrm{ml}$ of $\mathrm{MB}\left(\mathrm{C}_{0}=1.0 \times 10^{-5} \mathrm{~mol} \cdot \mathrm{L}^{-1}\right)$ solution were mixed and dispersed by ultrasonic for $10 \mathrm{~min}$, respectively. The suspension was stirred for 30 min until reached the surface-adsorption equilibrium. Then, a $250 \mathrm{~W}$ high pressure $\mathrm{Hg}$ lamp was used as light source to irradiate the mixture, which was till stirred for keeping the mixture in suspension. At 15, 30, 45, 60, 
75, 90, 105 and 120 mins, the sample $(4 \mathrm{ml})$ was withdrawn from the vessel and 1-4 was removed by several centrifugations, and the clear liquid was analyzed by using UV-vis spectrophotometer.

\section{X-ray Crystallography}

Bruker Smart Apex diffractometer was employed to collect Single crystal X-ray data of 1-4. The SHELXT and SHELXL-2014 within Olex2 were utilized to solve and refine the structure. ${ }^{1,2}$ All the non-hydrogen atoms were refined anisotropically. The crystallographic refinement data of 1-4 were listed and showed in Table S1, and selected bond lengths $(\AA)$ and angles $\left(^{\circ}\right)$ for $\mathbf{1 - 4}$ were summarized in Table S2.

(1) Sheldrick, G. M. SHELXT - Integrated space-group and crystal-structure determination. Acta Crystallogr., Sect. A: Found. Adv. 2015, 71, 3-8.

(2) Dolomanov,O. V.; Bourhis,L. J.; Gildea, R. J.; Howard,J. A. K.; Puschmann,H. OLEX2: a complete structure solution, refinement and analysis program. J. Appl. Crystallogr. 2009, 42, 339-341. 


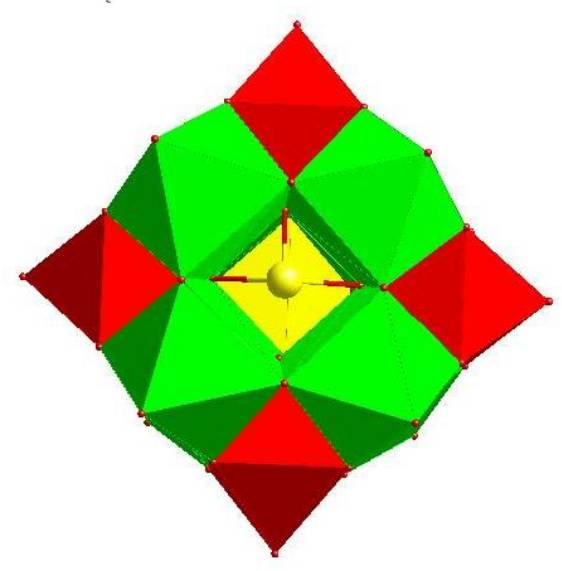

Figure S1 View of $\left\{\mathrm{As}_{3} \mathrm{Mo}_{8} \mathrm{~V}_{4}\right\}$ cluster.
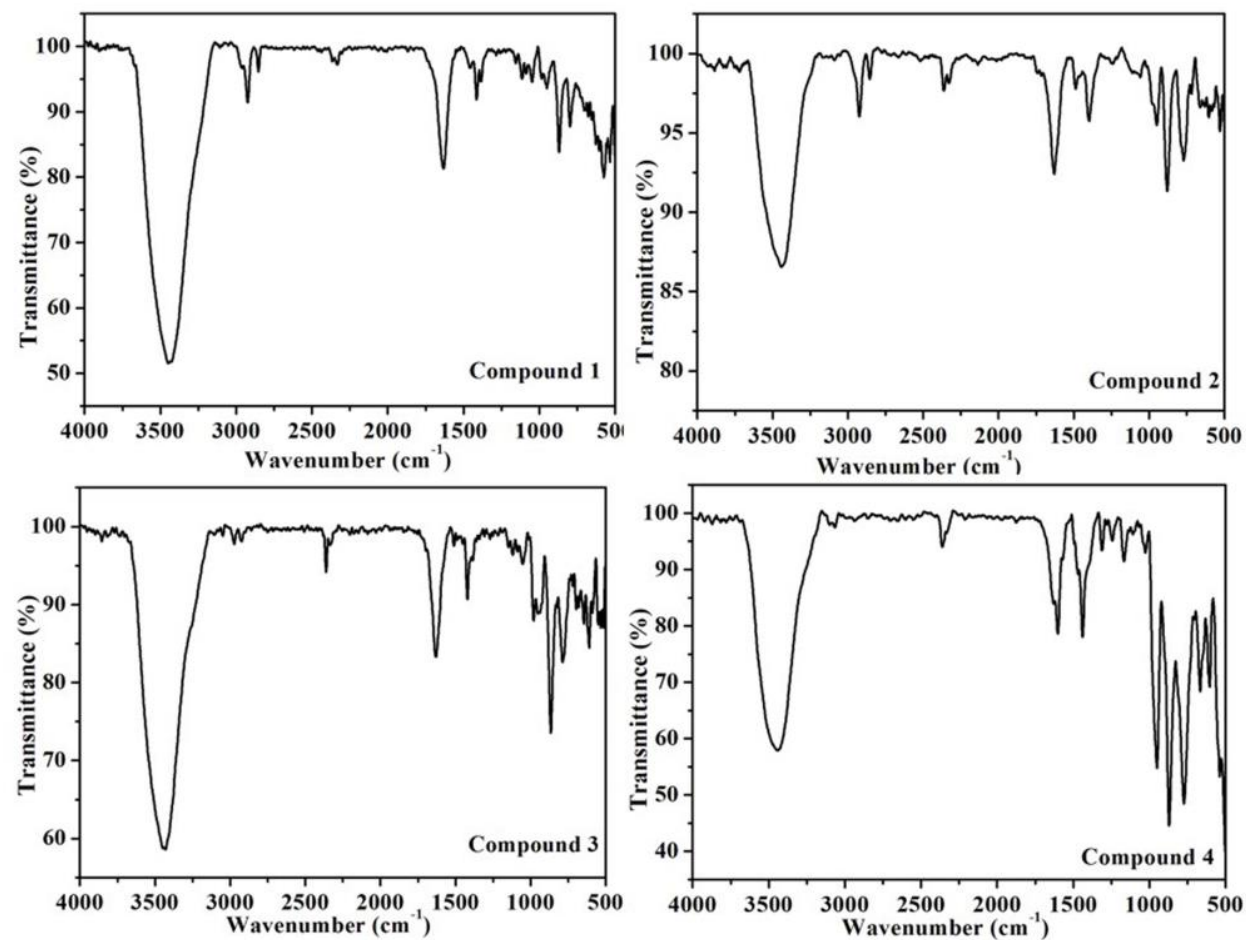

Figure S2 IR spectra of compounds 1-4.

\section{IR spectra}

The IR spectra of 1-4 were shown Fig. S2. The peaks at $2975-1159 \mathrm{~cm}^{-1}$ correspond to $v(\mathrm{~N}-\mathrm{N})$ and $v(\mathrm{C}-\mathrm{N})$ of the organic ligands. ${ }^{3}$ The peaks at $980-949$ $\mathrm{cm}^{-1}$ are attributed to $v\left(\mathrm{M}=\mathrm{O}_{\mathrm{t}}\right)(\mathrm{M}=\mathrm{Mo}$ or $\mathrm{V}) .{ }^{4}$ The peaks at $1058-1022 \mathrm{~cm}^{-1}$ and $877-862 \mathrm{~cm}^{-1}$ are assigned to $v\left(\right.$ As-O).${ }^{5}$ The peaks at $790-522 \mathrm{~cm}^{-1}$ are due to 
$v(\mathrm{M}-\mathrm{O}-\mathrm{M})(\mathrm{M}=\mathrm{Mo}$ or $\mathrm{V}){ }^{6}$ Besides, the broad bands at $3448-3438 \mathrm{~cm}^{-1}$ suggest the presence of $v(\mathrm{O}-\mathrm{H})$ and $v(\mathrm{~N}-\mathrm{H})$ in $\mathbf{1 - 4}$.

(3)Zhao,W.Q.; Su,Z.H.; Zhao,Z.F.; Cong,B.W.; Xia,L.; Zhou,B.B.The synthesis, structure and properties of a new compound with 1D linear chain arsenomolybdate anion building block.Inorg.Chem.Commun.2015,61,118-122.

(4)Cong,B.W.; Su,Z.H.; Zhao,Z.F.; Yu,B.Y.; Zhao,W.Q.; Ma,X.J. Two unusual 3D honeycomb networks based on Wells-Dawson arsenomolybdates with $\mathrm{d}^{10}$ transition-metal-pyrazole connectors. Dalton Trans. 2017,46, 7577-7583.

(5)Liu,G.D.; Li,X.; Wang,Y.L.; Zhou,K.F.; Cui,S.Y.; Sha,J.Q. Assembly of the first bivanadium-capping saturated Keggin type arsenovanadotungstate compound. Inorg.Chem.Commun. 2017,86,44-48.

(6)Yang,Y. Y.; Xu,L.; Jia,L. P.; Gao,G. G.; Li,F. Y.; Qu,X. S.; Qiu,Y. F. Crystal structure and electrochemical properties of the supramolecular compound [Himi $]_{6}\left[\mathrm{As}_{2} \mathrm{Mo}_{18} \mathrm{O}_{62}\right] \cdot 11 \mathrm{H}_{2} \mathrm{O}$. Cryst. Res. Technol. 2007, 42,1036-1040. 

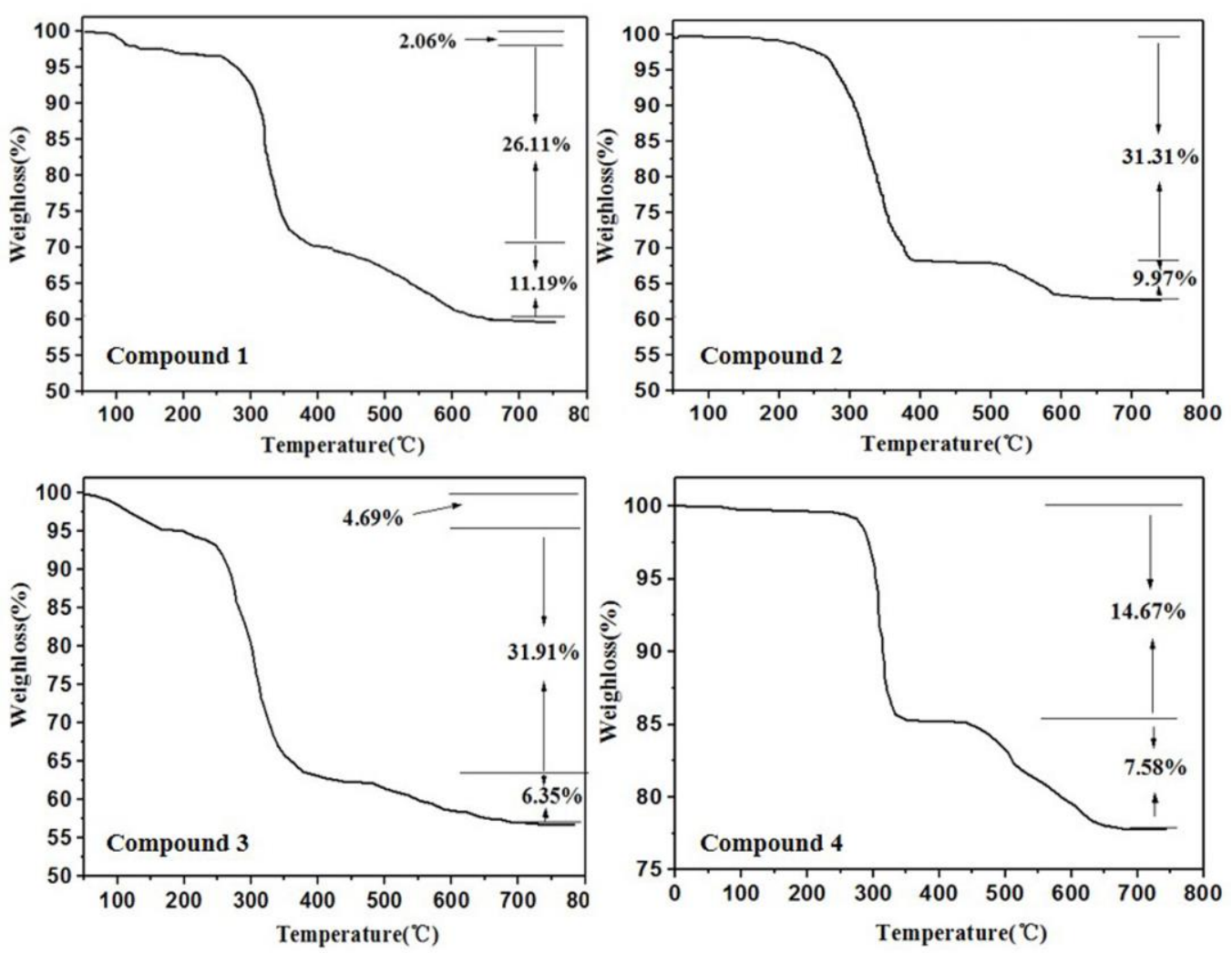

Figure S3 The TG curves of compounds 1-4.

\section{TG curves}

The thermal stabilities of $\mathbf{1 - 4}$ were investigated under $\mathrm{N}_{2}$ atmosphere with a heating rate of $10{ }^{\circ} \mathrm{C} \mathrm{min}^{-1}$ (as shown in Fig. S3). In the TG curve of $\mathbf{1}$, the first weight loss of $2.06 \%$ (calcd. $1.98 \%$ ) at $95-110{ }^{\circ} \mathrm{C}$ is attributed to the loss of free water molecules. The second weight loss of $26.10 \%$ (calcd. 26.15\%) between $295-350{ }^{\circ} \mathrm{C}$ arises from the loss of bix ligands. The third weight loss of $11.20 \%$ (calcd.11.15\%) at $410-608{ }^{\circ} \mathrm{C}$ is assigned to the decomposition of the framework. For 2, the first weight loss of $31.32 \%$ (calcd. $31.27 \%$ ) at 286-345 ${ }^{\circ} \mathrm{C}$ is assigned to the loss of the bib ligands. The second weight of $9.95 \%$ (calcd $10.02 \%)$ at $411-612^{\circ} \mathrm{C}$ is assigned to the decomposition of the polyoxoanion. In the TG curve of 3 , the first weight loss of $4.31 \%$ (calcd. $4.24 \%$ ) at $98-180{ }^{\circ} \mathrm{C}$ is 
attributed to the loss of water molecules. The second weight loss of $32.54 \%$ (calcd. $32.48 \%$ ) between $245-340{ }^{\circ} \mathrm{C}$ arises from the loss of organic ligand tib. The third weight loss of $6.32 \%$ (calcd $6.28 \%$ ) at $410-615^{\circ} \mathrm{C}$ is assigned to the decomposition of the framework. For 4, the first weight loss of $14.14 \%$ (calcd. $14.19 \%$ ) at $275-345{ }^{\circ} \mathrm{C}$ is assigned to the loss of the organic ligand bih. The second weight of $7.27 \%$ (calcd $7.22 \%$ ) at $415-610{ }^{\circ} \mathrm{C}$ is assigned to the decomposition of the $\left\{\mathrm{As}_{3} \mathrm{Mos}_{8} \mathrm{~V}_{4}\right\}$ polyoxoanion. All the weight losses from the TG curves are in accord with the formulas of 1-4.
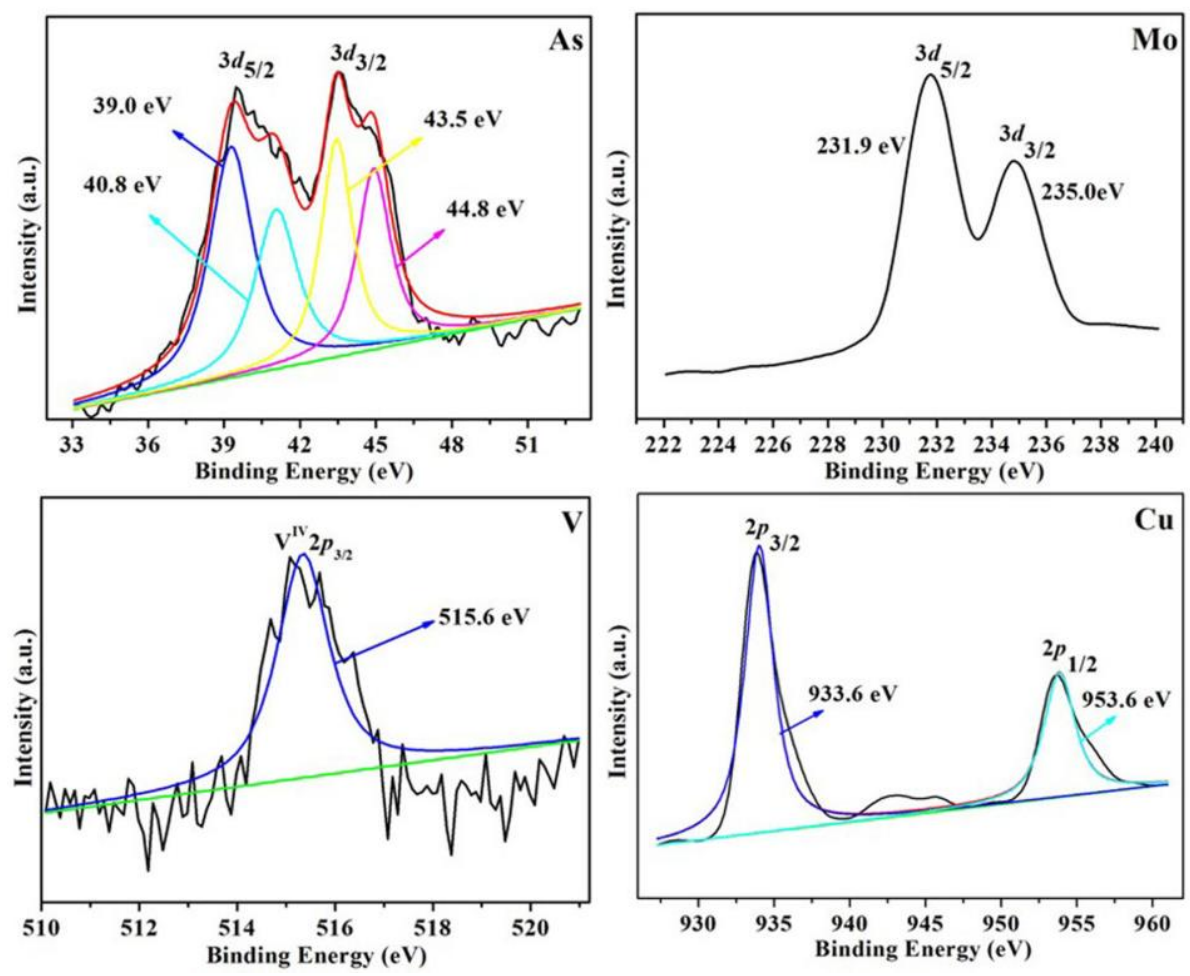

Figure S4 The XPS spectra of compound 1. 

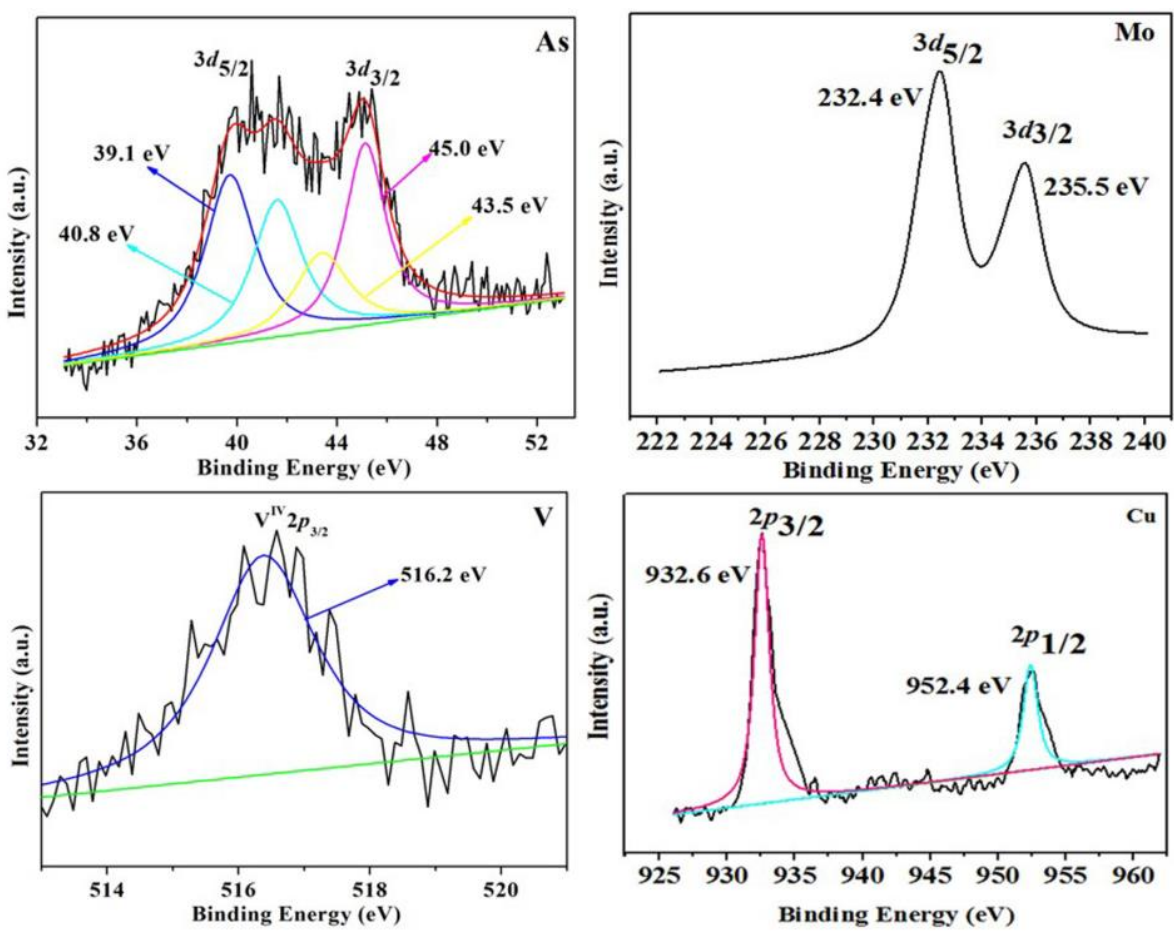

Figure S5 The XPS spectra of compound 2.
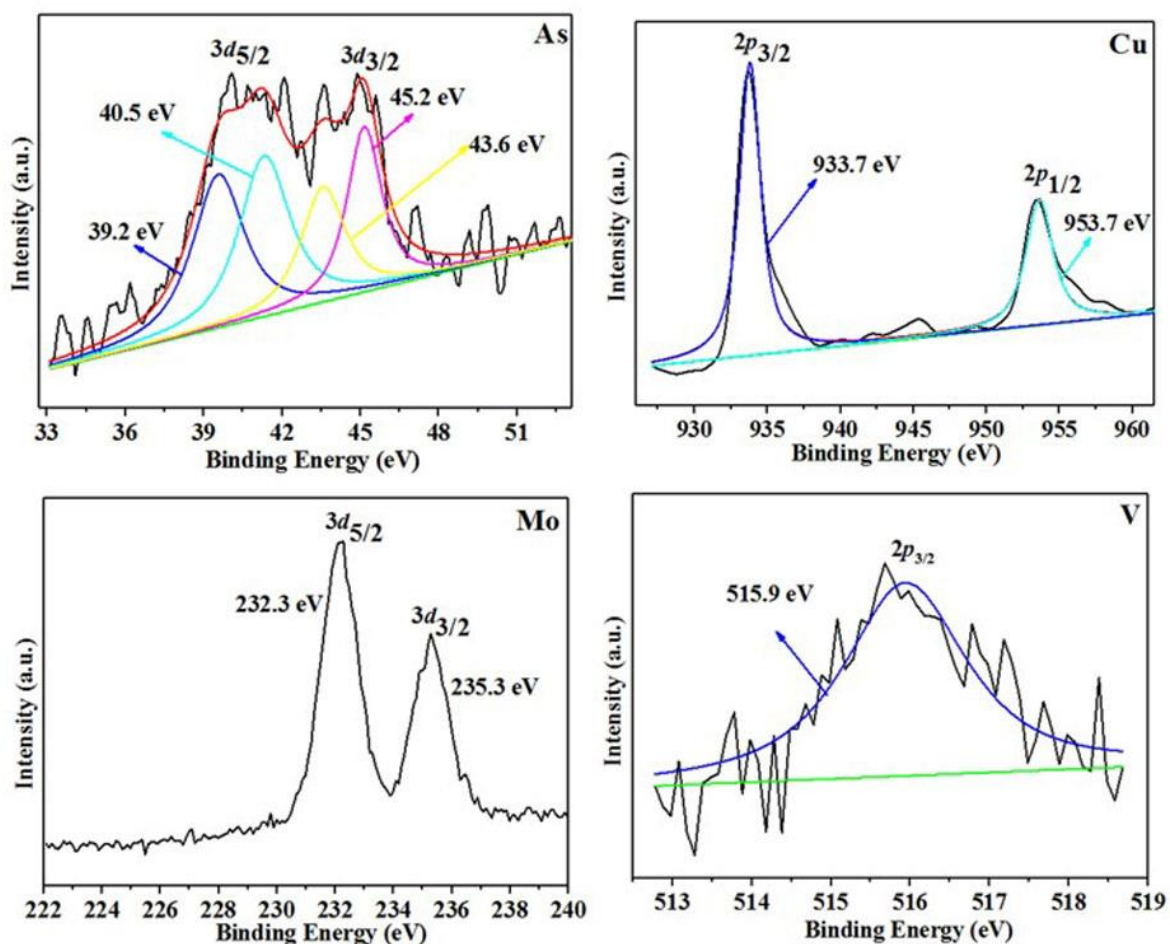

Figure S6 The XPS spectra of compound 3. 

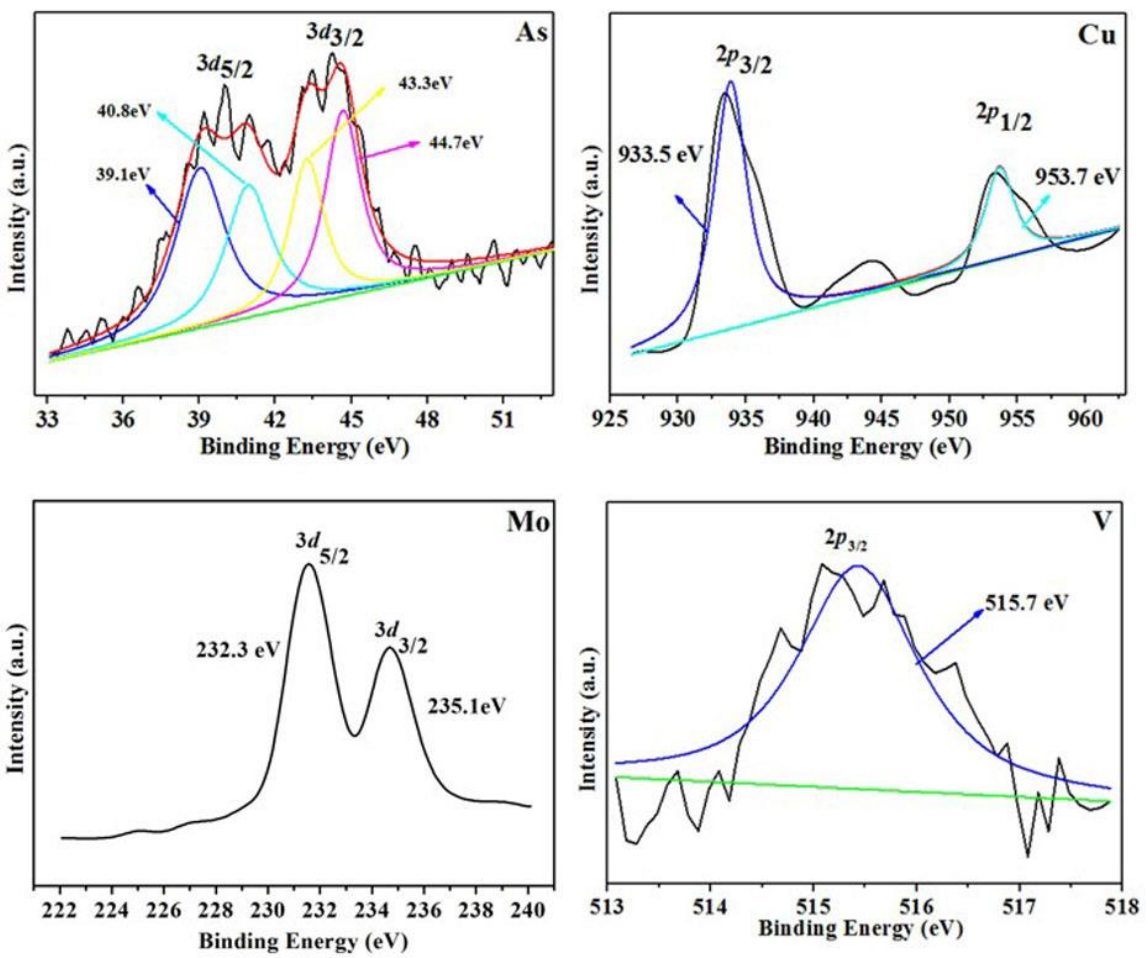

Figure S7 The XPS spectra of compound 4.

\section{XPS spectra}

The oxidation states of $\mathrm{Mo}, \mathrm{V}, \mathrm{As}$ and $\mathrm{Cu}$ for 1-4 are confirmed by XPS measurements, which were carried out in the energy region of Mo $3 d_{5 / 2}$ and Mo $3 d_{3 / 2}$, V $2 \mathrm{p}_{3 / 2}$, As $3 \mathrm{~d}_{5 / 2}$ and $\mathrm{As} 3 \mathrm{~d}_{3 / 2}, \mathrm{Cu} 2 \mathrm{p}_{3 / 2}$ and $\mathrm{Cu} 2 \mathrm{p}_{1 / 2}$, respectively (Figure S4-S7). The XPS spectra of 1-4 present two peaks at 231.9 and $235.0 \mathrm{eV}, 232.4$ and $235.5 \mathrm{eV}$, 232.3 and $235.3 \mathrm{eV}, 232.3$ and $235.1 \mathrm{eV}$ in the Mo $3 \mathrm{~d}_{5 / 2}$ and Mo $3 \mathrm{~d}_{3 / 2}$ regions, respectively, which are assigned to $\mathrm{Mo}^{\mathrm{VI}}{ }^{7}$ In the $\mathrm{V} 2 \mathrm{p}_{3 / 2}$ energy region presents the peak at 515.6, 516.2, 515.9 and $515.7 \mathrm{eV}$, respectively, which were ascribed to $\mathrm{V}^{\mathrm{IV}}$ ion. ${ }^{8}$ The characteristic bands at 40.8 and $44.8 \mathrm{eV}, 40.8$ and $45.0 \mathrm{eV}, 40.5$ and $45.2 \mathrm{eV}$, and 40.8 and $44.7 \mathrm{eV}$ in the $\mathrm{As} 3 \mathrm{~d}_{5 / 2}$ and $\mathrm{As} 3 \mathrm{~d}_{3 / 2}$ regions, which should be assigned to $\mathrm{As}^{\mathrm{V}},{ }^{9}$ and the characteristic bands at 39.0 and $43.5 \mathrm{eV}$, 
39.1 and 43.5eV, 39.2 and $43.6 \mathrm{eV}$, and 39.1 and $43.3 \mathrm{eV}$ in the $\mathrm{As} 3 \mathrm{~d}_{5 / 2}$ and $\mathrm{As}$ $3 \mathrm{~d}_{3 / 2}$ regions, which should be assigned to $\mathrm{As}{ }^{\mathrm{III}} .{ }^{10}$ While the XPS spectra give two peaks at 933.6 and $953.6 \mathrm{eV}, 932.6$ and $952.4 \mathrm{eV}, 933.7$ and $953.7 \mathrm{eV}, 933.5$ and $953.7 \mathrm{eV}$ in the $\mathrm{Cu} 2 \mathrm{p}_{3 / 2}$ and $\mathrm{Cu} 2 \mathrm{p}_{1 / 2}$ regions, respectively, which should be ascribed to $\mathrm{Cu}^{\mathrm{I}}{ }^{11}$

(7)Ranga,C.;Lødeng,R.;Alexiadis,V.I.;Rajkhowa,T.;Bjørkan,H.;Chytil,S.;Svenu m,I.H.;Walmsley,J.;Detavernier,C.;Poelman,H.;Van Der Voort,P.; Thybaut, J.W. Effect of composition and preparation of supported $\mathrm{MoO}_{3}$ catalysts for anisole hydrodeoxygenation.Chem.Eng. J. 2018, 335, 120-132.

(8)Zimmermann,R.; Claessen,R.; Reinert,F.; Steiner,P.; Hüfner,S. Strong hybridization in vanadium oxides: evidence from photoemission and absorption spectroscopy. J. Phys. Condens.Matter. 1998,10,5697-5716.

(9)Hou,Y.; Wei,Y.G.; Xiao,D.R.; Shen,E.H.; Wang,E.B.; Li,Y.G.; Xu,L.; Hu,C.W. Hydrothermal synthesis and crystal structure of a novel one-dimensional arsenic vanadate decorated with organonitrogen ligand: $\left[\mathrm{H}_{3} \mathrm{~V}_{3} \mathrm{O}_{26}\left(\mathrm{AsO}_{4}\right)_{4}(\text { phen })_{8}\right.$ $\left.\left(\mathrm{H}_{2} \mathrm{O}\right)_{2}\right] \cdot 2 \mathrm{H}_{2} \mathrm{O}$ (phen=phenanthroline). Inorg. Chim.Acta. 2004,357,2477-2482.

(10)Zhang,H.; Yu,K.; Wang,C. M.; Su,Z. H.; Wang,C. X.;Sun,D.; Cai,H. H.;Chen,Z. Y.;Zhou,B.B. pH and ligand dependent assembly of Well-Dawson arsenomolybdate capped architectures. Inorg. Chem. 2014, 53, 12337-12347. 
(11)Wang,K.P.;Yu,K.; Lv,J.H.; Zhang,M.L.;Meng,F.X. A host-guest supercapacitor electrode material based on a mixed hexa-transition metal sandwiched arsenotungstate Chain and three-dimensional supramolecular metal-organic networks with one-dimensional cavities. Inorg. Chem. 2019, 58, 7947-7957.
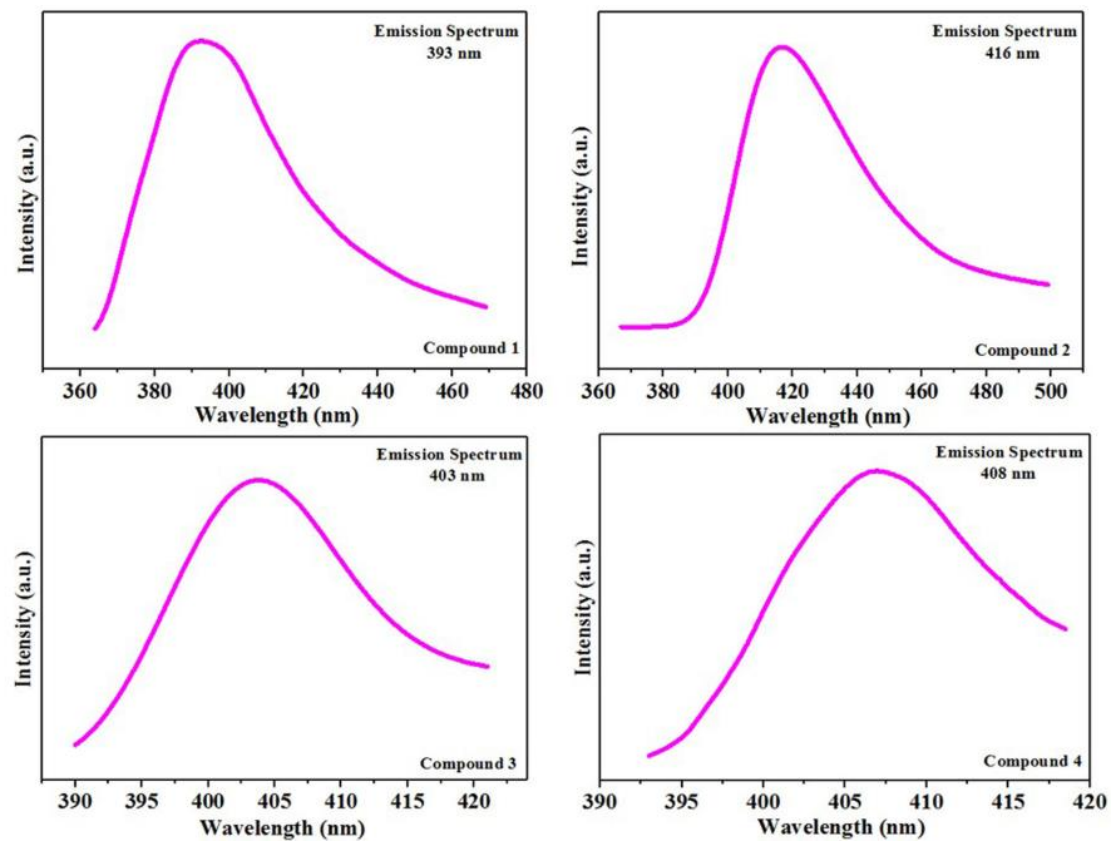

Figure S8 The solid state fluorescent spectra of 1-4 at room temperature.

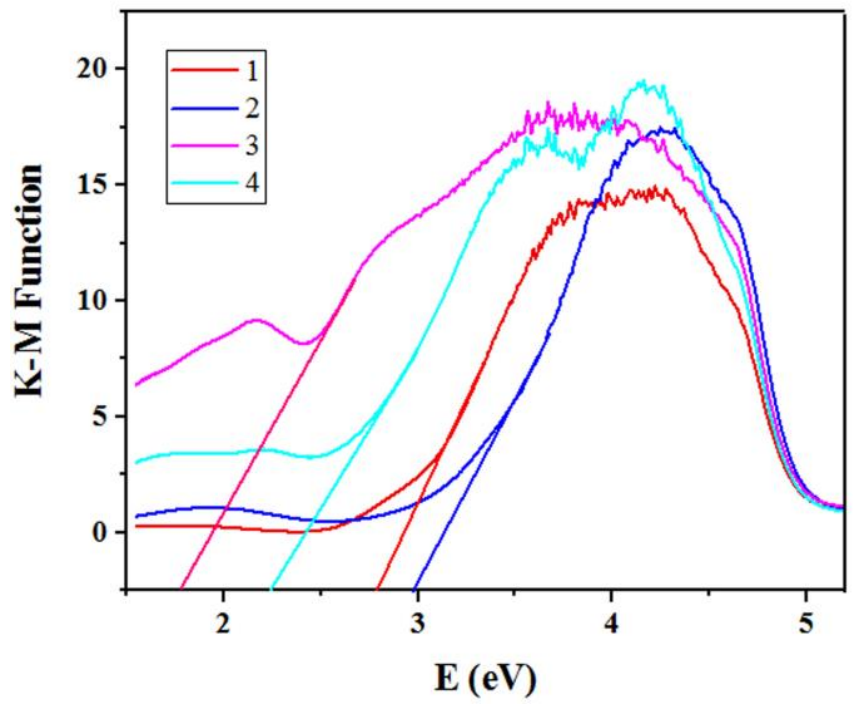

Figure S9 Diffuse reflection spectrum of Kubelka-Munk (K-M) function versus energy $(\mathrm{eV})$ of $\mathbf{1 - 4}$. 

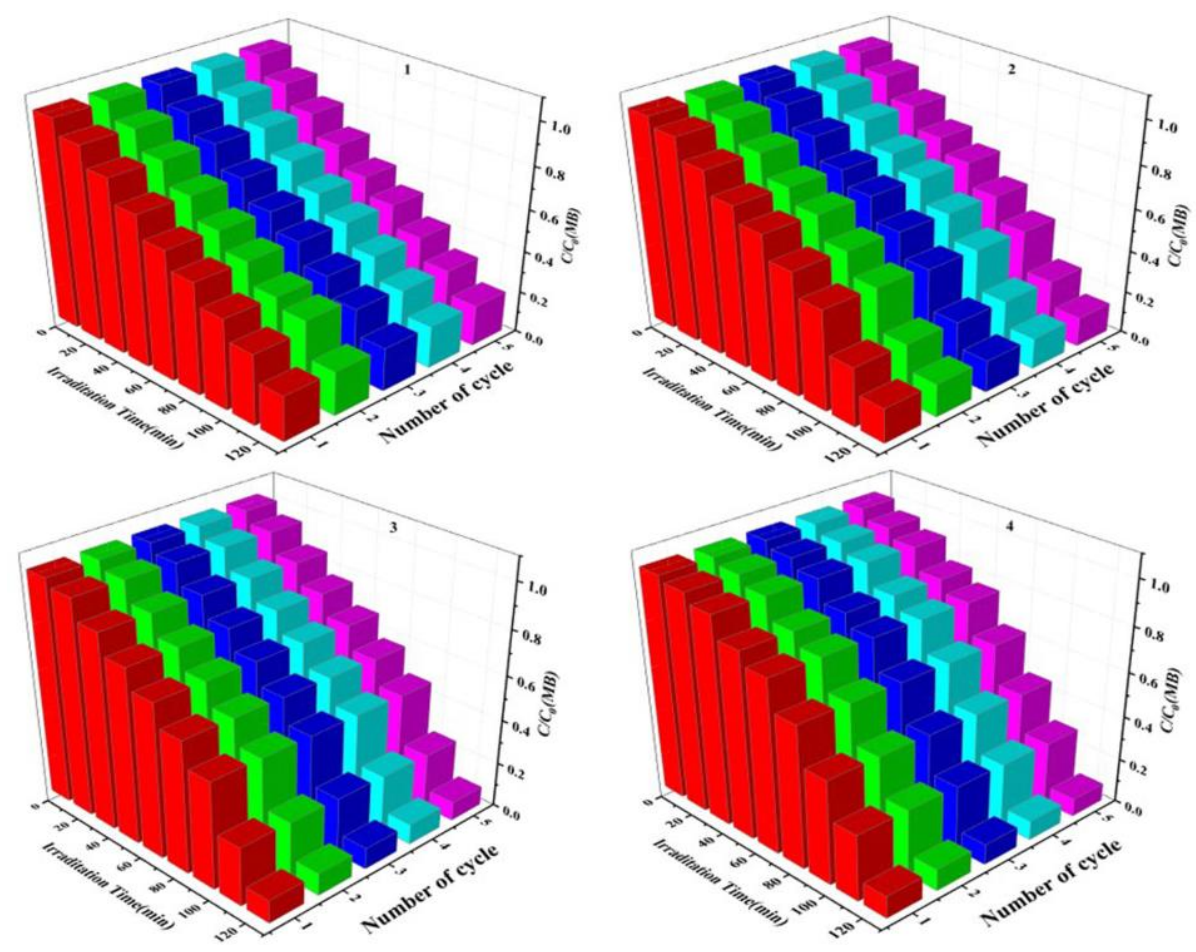

Figure S10 Photo-degradation of the MB solution by 1-4 as the catalyst, recycled 5 times.
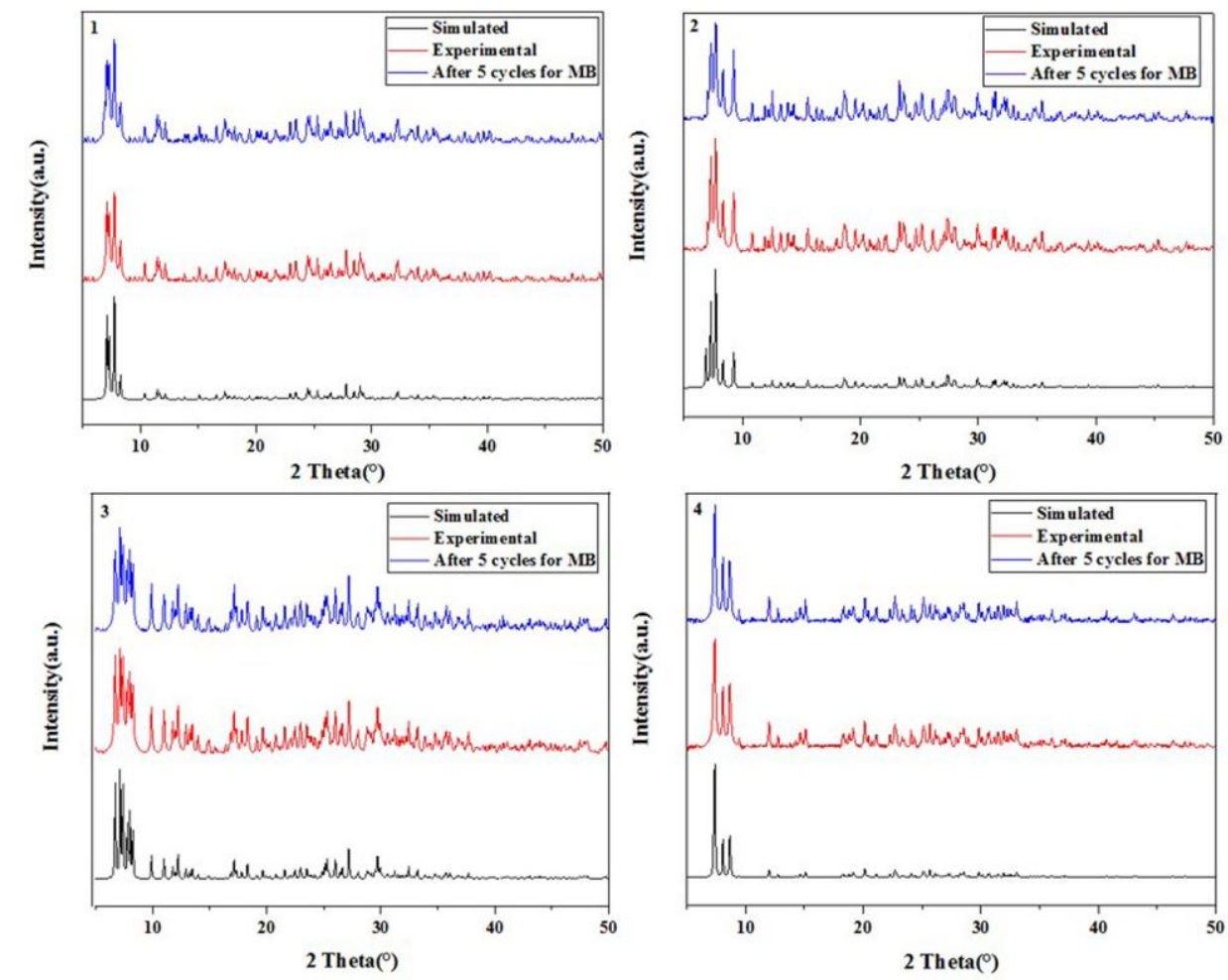

Figure S11 The XRD patterns of 1-4 before and after MB degradation for five cycles. 
Table S1 Crystallographic and structural refinement data for 1-4

\begin{tabular}{|c|c|c|c|c|}
\hline & 1 & 2 & 3 & 4 \\
\hline $\begin{array}{l}\text { Empirical } \\
\text { formula }\end{array}$ & $\begin{array}{c}\mathrm{C}_{42} \mathrm{H}_{50} \mathrm{As}_{3} \mathrm{Cu}_{2} \mathrm{M} \\
{ }_{0} \mathrm{~N}_{12} \mathrm{O}_{43} \mathrm{~V}_{4}\end{array}$ & $\begin{array}{c}\mathrm{C}_{56} \mathrm{H}_{54} \mathrm{As}_{3} \mathrm{Cu}_{4} \mathrm{M} \\
{ }_{\mathrm{O}_{8}} \mathrm{~N}_{16} \mathrm{O}_{40} \mathrm{~V}_{4}\end{array}$ & $\begin{array}{c}\mathrm{C}_{60} \mathrm{H}_{64} \mathrm{Ass}_{3} \mathrm{Cu}_{5} \mathrm{M} \\
\mathrm{O}_{8} \mathrm{~N}_{24} \mathrm{O}_{48} \mathrm{~V}_{4}\end{array}$ & $\begin{array}{c}\mathrm{C}_{48} \mathrm{H}_{72} \mathrm{As}_{3} \mathrm{Cu}_{4} \mathrm{M} \\
\mathrm{O}_{8} \mathrm{~N}_{16} \mathrm{O}_{40} \mathrm{~V}_{4}\end{array}$ \\
\hline$T[\mathrm{~K}]$ & 298 & 296.15 & 100 & 296.15 \\
\hline Crystal system & triclinic & triclinic & triclinic & Monoclinic \\
\hline Space group & $P-1$ & $P-1$ & $P-1$ & P $121 /$ n 1 \\
\hline$a[\AA]$ & $10.7782(10)$ & $13.0821(9)$ & $12.8735(10)$ & $13.9487(12)$ \\
\hline$b[\AA]$ & $13.4165(12)$ & $13.6264(9)$ & $14.5001(12)$ & $14.7536(12)$ \\
\hline$c[\AA]$ & $13.7264(13)$ & $14.2290(10)$ & $15.3234(12)$ & $20.5838(17)$ \\
\hline$\alpha\left[^{\circ}\right]$ & $114.5250(10)$ & $65.4180(10)$ & $113.3560(10)$ & 90 \\
\hline$\beta\left[^{\circ}\right]$ & $92.8970(10)$ & $89.1460(10)$ & $100.3820(10)$ & $96.1230(10)$ \\
\hline$\gamma\left[^{\circ}\right]$ & $95.0480(10)$ & $69.1390(10)$ & $109.2650(10)$ & 90 \\
\hline $\mathrm{V},\left(\AA^{3}\right)$ & $1790.5(3)$ & $2128.7(3)$ & $2313.8(3)$ & $4211.8(6)$ \\
\hline $\mathrm{Z}$ & 1 & 1 & 1 & 2 \\
\hline$\mu\left[\mathrm{mm}^{-1}\right]$ & 3.908 & 3.780 & 3.722 & 3.817 \\
\hline$D_{c},\left[\mathrm{Mg} \mathrm{cm}^{-3}\right]$ & 2.536 & 2.372 & 2.442 & 2.337 \\
\hline $\mathrm{GOF}$ on $\mathrm{F}^{2}$ & 1.137 & 1.033 & 1.273 & 1.024 \\
\hline $\begin{array}{l}\text { final } R \text { indices } \\
{[\mathrm{I}>2 \sigma(\mathrm{I})]}\end{array}$ & $\begin{array}{c}R_{1}=0.0493 \\
w R_{2}=0.1224\end{array}$ & $\begin{array}{c}R_{1}=0.0496 \\
w R_{2}=0.1253\end{array}$ & $\begin{array}{c}R_{1}=0.0775 \\
w R_{2}=0.1491\end{array}$ & $\begin{array}{r}R_{1}=0.0439 \\
w R_{2}=0.1104\end{array}$ \\
\hline
\end{tabular}

Table S2 Selected bond lengths $(\AA)$ and bond angles $\left(^{\circ}\right)$ of compounds 1-4

\begin{tabular}{|c|c|c|c|c|c|}
\hline \multicolumn{6}{|c|}{ Compound 1} \\
\hline $\mathrm{Mo}(1)-\mathrm{O}(22)$ & $1.645(6)$ & $\operatorname{Mo}(1)-\mathrm{O}(11)$ & $1.969(12)$ & $\mathrm{Mo}(2)-\mathrm{O}(20)$ & $1.896(11)$ \\
\hline $\mathrm{Mo}(2)-\mathrm{O}(2)$ & $2.379(9)$ & $\mathrm{Mo}(3)-\mathrm{O}(7)$ & $1.707(11)$ & $\mathrm{Mo}(3)-\mathrm{O}(14) \# 1$ & $1.713(14)$ \\
\hline $\mathrm{Mo}(4)-\mathrm{O}(17)$ & $1.661(5)$ & $\mathrm{Mo}(4)-\mathrm{O}(1)$ & $2.432(9)$ & $\operatorname{As}(1)-\mathrm{O}(5)$ & $1.716(9)$ \\
\hline $\operatorname{As}(1)-\mathrm{O}(2)$ & $1.677(9)$ & $\operatorname{As}(2)-\mathrm{O}(9)$ & $1.776(11)$ & $\operatorname{As}(2)-\mathrm{O}(10)$ & $1.827(18)$ \\
\hline $\mathrm{Cu}(1)-\mathrm{N}(4) \# 2$ & $1.875(7)$ & $\mathrm{Cu}(1)-\mathrm{N}(1)$ & $1.871(7)$ & $\mathrm{V}(1)-\mathrm{O}(7)$ & $1.855(11)$ \\
\hline $\mathrm{V}(1)-\mathrm{O}(8)$ & $1.908(13)$ & $\mathrm{V}(2)-\mathrm{O}(14)$ & $1.883(14)$ & $\mathrm{V}(2)-\mathrm{O}(1)$ & $2.361(9)$ \\
\hline $\mathrm{O}(22)-\mathrm{Mo}(1)-\mathrm{O}(11)$ & $109.0(4)$ & $\mathrm{O}(22)-\mathrm{Mo}(1)-\mathrm{O}(6)$ & $113.0(5)$ & $\mathrm{O}(3)-\mathrm{Mo}(2)-\mathrm{O}(2)$ & $69.4(4)$ \\
\hline $\mathrm{O}(20)-\mathrm{Mo}(2)-\mathrm{O}(10)$ & $151.0(5)$ & $\mathrm{O}(19)-\mathrm{Mo}(3)-\mathrm{O}(11)$ & $108.8(4)$ & $\mathrm{O}(7)-\mathrm{Mo}(3)-\mathrm{O}(10)$ & $133.5(6)$ \\
\hline $\mathrm{O}(17)-\mathrm{Mo}(4)-\mathrm{O}(3)$ & $92.6(4)$ & $\mathrm{O}(12)-\mathrm{Mo}(4)-\mathrm{O}(3)$ & $150.8(5)$ & $\mathrm{O}(2)-\mathrm{As}(1)-\mathrm{O}(5)$ & $111.0(4)$ \\
\hline $\mathrm{O}(4)-\operatorname{As}(1)-\mathrm{O}(2)$ & $68.6(4)$ & $\mathrm{O}(9)-\mathrm{As}(2)-\mathrm{O}(3)$ & $81.4(5)$ & $\mathrm{O}(11)-\mathrm{As}(2)-\mathrm{O}(3)$ & $124.3(5)$ \\
\hline $\mathrm{O}(7)-\mathrm{V}(1)-\mathrm{O}(6)$ & $87.2(5)$ & $\mathrm{O}(18)-\mathrm{V}(1)-\mathrm{O}(6)$ & $111.8(5)$ & $\mathrm{O}(16)-\mathrm{V}(2)-\mathrm{O}(15)$ & $111.2(5)$ \\
\hline $\mathrm{O}(16)-\mathrm{V}(2)-\mathrm{O}(1)$ & $156.2(4)$ & $\mathrm{N}(1)-\mathrm{Cu}(1)-\mathrm{N}(4) \# 2$ & $169.6(4)$ & $\mathrm{N}(1)-\mathrm{Cu}(1)-\mathrm{O}(6 \mathrm{~A})$ & $99.8(4)$ \\
\hline \multicolumn{6}{|c|}{ Symmetry transformations used to generate equivalent atoms: $\# 1-x-1,-y+2,-z+1$} \\
\hline \multicolumn{6}{|c|}{ Compound 2} \\
\hline $\mathrm{Mo}(1)-\mathrm{O}(2) \# 1$ & $2.059(15)$ & $\mathrm{Mo}(1)-\mathrm{O}(15)$ & $1.740(10)$ & $\mathrm{Mo}(2)-\mathrm{O}(6)$ & $2.013(8)$ \\
\hline $\mathrm{Mo}(2)-\mathrm{O}(11)$ & $1.623(8)$ & $\operatorname{Mo}(3)-\mathrm{O}(4)$ & $1.944(9)$ & $\mathrm{Mo}(3)-\mathrm{O}(19)$ & $2.322(7)$ \\
\hline $\mathrm{Mo}(4)-\mathrm{O}(7)$ & $1.73(2)$ & $\mathrm{Mo}(4)-\mathrm{O}(9)$ & $1.639(8)$ & $\operatorname{As}(1)-\mathrm{O}(19)$ & $1.741(7)$ \\
\hline $\operatorname{As}(1)-\mathrm{O}(20)$ & $1.592(7)$ & $\operatorname{As}(2)-\mathrm{O}(2)$ & $1.951(18)$ & $\operatorname{As}(2)-\mathrm{O}(6)$ & $1.702(8)$ \\
\hline
\end{tabular}




\begin{tabular}{llllll}
\hline $\mathrm{V}(1)-\mathrm{O}(4)$ & $2.112(9)$ & $\mathrm{V}(1)-\mathrm{O}(13)$ & $1.981(9)$ & $\mathrm{V}(2)-\mathrm{O}(9)$ & $1.922(8)$ \\
$\mathrm{V}(2)-\mathrm{O}(10)$ & $1.582(4)$ & $\mathrm{Cu}(1)-\mathrm{N}(1)$ & $1.887(5)$ & $\mathrm{Cu}(1)-\mathrm{N}(3)$ & $1.874(6)$ \\
$\mathrm{O}(2) \# 1-\mathrm{Mo}(1)-\mathrm{O}(16)$ & $71.3(6)$ & $\mathrm{O}(15)-\mathrm{Mo}(1)-\mathrm{O}(18)$ & $99.1(6)$ & $\mathrm{O}(6)-\mathrm{Mo}(2)-\mathrm{O}(3)$ & $70.6(3)$ \\
$\mathrm{O}(11)-\mathrm{Mo}(2)-\mathrm{O}(3)$ & $152.8(4)$ & $\mathrm{O}(1)-\mathrm{Mo}(3)-\mathrm{O}(2)$ & $92.3(4)$ & $\mathrm{O}(2)-\mathrm{Mo}(3)-\mathrm{O}(19)$ & $95.5(4)$ \\
$\mathrm{O}(7)-\mathrm{Mo}(4)-\mathrm{O}(6)$ & $112.4(9)$ & $\mathrm{O}(8)-\mathrm{Mo}(4)-\mathrm{O}(6)$ & $135.9(4)$ & $\mathrm{O}(20)-\mathrm{As}(1)-\mathrm{O}(19)$ & $109.2(3)$ \\
$\mathrm{O}(20) \# 1-\mathrm{As}(1)-\mathrm{O}(19)$ & $70.8(3)$ & $\mathrm{O}(2)-\mathrm{As}(2)-\mathrm{O}(3)$ & $82.4(5)$ & $\mathrm{O}(6)-\mathrm{As}(2)-\mathrm{O}(2)$ & $122.8(4)$ \\
$\mathrm{O}(4)-\mathrm{V}(1)-\mathrm{O}(19)$ & $70.1(3)$ & $\mathrm{O}(14)-\mathrm{V}(1)-\mathrm{O}(15)$ & $112.4(4)$ & $\mathrm{O}(9)-\mathrm{V}(2)-\mathrm{O}(18)$ & $149.5(4)$ \\
$\mathrm{O}(10)-\mathrm{V}(2)-\mathrm{O}(11)$ & $114.5(3)$ & $\mathrm{N}(3)-\mathrm{Cu}(1)-\mathrm{N}(1)$ & $172.8(2)$ & $\mathrm{N}(8)-\mathrm{Cu}(3)-\mathrm{N}(8) \# 2$ & 180.0
\end{tabular}

Symmetry transformations used to generate equivalent atoms: $\# 1-\mathrm{x},-\mathrm{y}+1,-\mathrm{z}+1 ; \# 2-\mathrm{x},-\mathrm{y}+3,-\mathrm{z}$

\begin{tabular}{llllll}
\multicolumn{7}{l}{ Symmetry transformations used to generate equivalent atoms:\#1 -x,-y+1,-Z+1; 2 - $\mathrm{x}, \mathrm{-}+3,-\mathrm{Z}$} \\
$\mathrm{M}(\mathrm{r})-\mathrm{O}(23)$ & $1.662(7)$ & $\mathrm{Mo}(1)-\mathrm{O}(22)$ & $1.911(18)$ & $\mathrm{Mo}(2)-\mathrm{O}(20)$ & $1.680(8)$ \\
$\mathrm{Mo}(2)-\mathrm{O}(13)$ & $1.974(17)$ & $\mathrm{Mo}(3)-\mathrm{O}(10)$ & $1.691(15)$ & $\mathrm{Mo}(3)-\mathrm{O}(11)$ & $1.934(18)$ \\
$\mathrm{Mo}(4)-\mathrm{O}(8)$ & $1.699(16)$ & $\mathrm{Mo}(4)-\mathrm{O}(14)$ & $1.929(15)$ & $\mathrm{As}(1)-\mathrm{O}(2)$ & $1.698(13)$ \\
$\mathrm{As}(1)-\mathrm{O}(1)$ & $1.674(12)$ & $\mathrm{As}(2)-\mathrm{O}(5)$ & $1.808(19)$ & $\mathrm{As}(2)-\mathrm{O}(4)$ & $1.999(18)$ \\
$\mathrm{Cu}(1)-\mathrm{O}(14)$ & $2.446(15)$ & $\mathrm{Cu}(1)-\mathrm{N}(1)$ & $1.904(10)$ & $\mathrm{Cu}(2)-\mathrm{N}(6) \# 2$ & $1.885(9)$ \\
$\mathrm{Cu}(2)-\mathrm{N}(4)$ & $1.906(9)$ & $\mathrm{Cu}(3)-\mathrm{N}(10) \# 2$ & $1.893(8)$ & $\mathrm{Cu}(3)-\mathrm{O}(24)$ & $2.464(12)$ \\
$\mathrm{V}(1)-\mathrm{O}(17)$ & $1.574(8)$ & $\mathrm{V}(1)-\mathrm{O}(13)$ & $2.030(17)$ & $\mathrm{V}(2)-\mathrm{O}(19)$ & $1.556(8)$ \\
$\mathrm{V}(2)-\mathrm{O}(2)$ & $2.358(12)$ & $\mathrm{O}(23)-\mathrm{Mo}(1)-\mathrm{O}(3)$ & $92.4(6)$ & $\mathrm{O}(12)-\mathrm{Mo}(1)-\mathrm{O}(1)$ & $110.2(6)$ \\
$\mathrm{O}(20)-\mathrm{Mo}(2)-\mathrm{O}(6)$ & $89.5(5)$ & $\mathrm{O}(3)-\mathrm{Mo}(2)-\mathrm{O}(6)$ & $79.4(7)$ & $\mathrm{O}(18)-\mathrm{Mo}(3)-\mathrm{O}(10)$ & $113.8(7)$ \\
$\mathrm{O}(10)-\mathrm{Mo}(3)-\mathrm{O}(9)$ & $87.0(7)$ & $\mathrm{O}(15)-\mathrm{Mo}(4)-\mathrm{O}(8)$ & $115.9(6)$ & $\mathrm{O}(8)-\mathrm{Mo}(4)-\mathrm{O}(14)$ & $98.8(7)$ \\
$\mathrm{O}(1) \# 1-\mathrm{As}(1)-\mathrm{O}(2)$ & $68.5(6)$ & $\mathrm{O}(9)-\mathrm{As}(1)-\mathrm{O}(21)$ & $113.3(6)$ & $\mathrm{O}(6)-\mathrm{As}(2)-\mathrm{Mo}(1)$ & $113.4(5)$ \\
$\mathrm{O}(5)-\mathrm{As}(2)-\mathrm{O}(3)$ & $124.4(8)$ & $\mathrm{O}(14)-\mathrm{Cu}(1)-\mathrm{O}(15)$ & $62.7(4)$ & & \\
$\mathrm{N}(1)-\mathrm{Cu}(1)-\mathrm{O}(15)$ & $90.8(4)$ & $\mathrm{N}(4)-\mathrm{Cu}(2)-\mathrm{O}(16)$ & $97.1(4)$ & $\mathrm{N}(6) \# 2-\mathrm{Cu}(2)-\mathrm{N}(4)$ & $160.6(5)$ \\
$\mathrm{N}(7)-\mathrm{Cu}(3)-\mathrm{N}(10) \# 2$ & $165.7(4)$ & $\mathrm{N}(10) \# 2-\mathrm{Cu}(3)-\mathrm{O}(24)$ & $95.7(4)$ & $\mathrm{O}(13)-\mathrm{V}(1)-\mathrm{O}(9)$ & $106.4(6)$ \\
$\mathrm{O}(12)-\mathrm{V}(1)-\mathrm{O}(11)$ & $98.4(8)$ & $\mathrm{O}(19)-\mathrm{V}(2)-\mathrm{O}(2)$ & $156.0(5)$ & $\mathrm{O}(19)-\mathrm{V}(2)-\mathrm{O}(1) \# 1$ & $157.0(5)$
\end{tabular}

Symmetry transformations used to generate equivalent atoms: \#1 -x+1,-y+1,-z+1; \#2 x+1,y,z

\begin{tabular}{llllll}
\hline \multicolumn{5}{c}{} & \multicolumn{4}{c}{ Compound 4} \\
$\mathrm{Mo}(1)-\mathrm{O}(3)$ & $1.953(12)$ & $\mathrm{Mo}(1)-\mathrm{O}(19)$ & $1.660(5)$ & $\mathrm{Mo}(2)-\mathrm{O}(21)$ & $1.655(4)$ \\
$\mathrm{Mo}(2)-\mathrm{O}(7) \# 1$ & $2.474(8)$ & $\mathrm{Mo}(3)-\mathrm{O}(9)$ & $1.869(13)$ & $\mathrm{Mo}(3)-\mathrm{O}(7)$ & $2.404(8)$ \\
$\mathrm{Mo}(4)-\mathrm{O}(14)$ & $1.894(12)$ & $\mathrm{Mo}(4)-\mathrm{O}(15)$ & $2.102(11)$ & $\mathrm{As}(1)-\mathrm{O}(4)$ & $1.713(7)$ \\
$\mathrm{As}(1)-\mathrm{O}(6)$ & $1.614(7)$ & $\mathrm{As}(2)-\mathrm{O}(10)$ & $2.009(12)$ & $\mathrm{As}(2)-\mathrm{O}(12)$ & $1.969(15)$ \\
$\mathrm{Cu}(1)-\mathrm{N}(1)$ & $1.870(7)$ & $\mathrm{Cu}(1)-\mathrm{N}(7) \# 2$ & $1.864(7)$ & $\mathrm{Cu}(2)-\mathrm{O}(19)$ & $2.467(5)$ \\
$\mathrm{Cu}(2)-\mathrm{N}(3)$ & $1.880(6)$ & $\mathrm{V}(1)-\mathrm{O}(20)$ & $1.577(5)$ & $\mathrm{V}(1)-\mathrm{O}(2)$ & $1.949(11)$ \\
$\mathrm{V}(2)-\mathrm{O}(1)$ & $1.925(10)$ & $\mathrm{V}(2)-\mathrm{O}(22)$ & $1.573(5)$ & $\mathrm{O}(19)-\mathrm{Mo}(1)-\mathrm{O}(18)$ & $93.1(3)$ \\
$\mathrm{O}(3)-\mathrm{Mo}(1)-\mathrm{O}(4)$ & $110.2(3)$ & $\mathrm{O}(1)-\mathrm{Mo}(2)-\mathrm{O}(2)$ & $83.0(5)$ & $\mathrm{O}(21)-\mathrm{Mo}(2)-\mathrm{O}(2)$ & $113.5(4)$ \\
$\mathrm{O}(9)-\mathrm{Mo}(3)-\mathrm{O}(10)$ & $161.8(5)$ & $\mathrm{O}(8)-\mathrm{Mo}(3)-\mathrm{O}(10)$ & $91.6(4)$ & $\mathrm{O}(16)-\mathrm{Mo}(4)-\mathrm{O}(12)$ & $91.9(4)$ \\
$\mathrm{O}(15)-\mathrm{Mo}(4)-\mathrm{O}(12)$ & $77.2(5)$ & $\mathrm{O}(6)-\mathrm{As}(1)-\mathrm{O}(4)$ & $67.0(4)$ & $\mathrm{O}(5)-\mathrm{As}(1)-\mathrm{O}(7) \# 1$ & $112.2(4)$ \\
$\mathrm{O}(12)-\mathrm{As}(2)-\mathrm{O}(10)$ & $83.9(5)$ & $\mathrm{O}(15)-\mathrm{As}(2)-\mathrm{O}(11)$ & $85.5(4)$ & $\mathrm{N}(7) \# 2-\mathrm{Cu}(1)-\mathrm{N}(1)$ & $163.8(3)$ \\
$\mathrm{N}(1)-\mathrm{Cu}(1)-\mathrm{O}(16)$ & $108.3(2)$ & $\mathrm{N}(3)-\mathrm{Cu}(2)-\mathrm{O}(19)$ & $94.8(2)$ & $\mathrm{N}(3)-\mathrm{Cu}(2)-\mathrm{N}(6) \# 2$ & $166.8(3)$ \\
$\mathrm{O}(20)-\mathrm{V}(1)-\mathrm{O}(3)$ & $92.4(4)$ & $\mathrm{O}(2)-\mathrm{V}(1)-\mathrm{O}(3)$ & $153.5(5)$ & $\mathrm{O}(22)-\mathrm{V}(2)-\mathrm{O}(9)$ & $93.6(4)$ \\
$\mathrm{O}(13)-\mathrm{V}(2)-\mathrm{O}(4) \# 1$ & $103.7(4)$ & & & \\
$\mathrm{Symmetry}$ transformations used to generate equivalent atoms: \#1 -x+1,-y+1,-z+1 & & \\
\hline
\end{tabular}

